\title{
230 界面活性剤添加による抵抗低減流れの乱流特性
}

\author{
川口靖夫○（機械技術研究所）、李 沛文(機械技術研究所、(財)省エネルギーセンター)、 \\ 矢部 彰（機械技術研究所）、菱田公一(慶應義塾大学)、前田昌信 (慶應義塾大学)
}

\section{Turbulent characteristics of drag reducing flow by surfactant additives \\ Yasuo Kawaguchi, Li Peiwen, Akira Yabe, Koichi Hishida and Masanobu Maeda}

\begin{abstract}
It is known that frictional drag in turbulent flow can be reduced considerably by adding a small amount of surfactant to the fluid. In order to investigate the mechanism of this phenomenon, the turbulent characteristics in surfactant aqueous solution flow in a planer two-dimensional channel has been investigated through visualization by dye injection, velocity measurements by LDV and time scale measurements through temperature fluctuation. Analysis of velocity fluctuation showed that Reynolds shear stress and turbulence production is diminished in drag reducing flow. Coherent structure was not obvious in this flow. It was observed that integral time scale become large near the wall. This finding suggests smaller dissipation and weakening of cascade process of turbulence energy. Lower turbulent diffusion can be explained by these characteristics found in drag reducing flow.
\end{abstract}

Key words: Drag reduction, Surfactant, Visualization, LDV, Turbulent stress, Time scale, Coherent structure

\section{1.はじめに}

特定の界面活性剂を水流に添加すると、乱流抑制によ って $80 \%$ という大きな抵抗低减効果を容易に得られる。 界面活性剂による抵抗低減は特性が安定しており、添加 凨は安価で効果が大きいことから、地域冷暖房などの実 システムへの応用が活発に議論されており ${ }^{1}$ 、著者らも 熱システムへ応用する場合に問題となる伝熱促進に関す る一連の研究を行っている2) 6)。

抵抗低減の大きさは比較的簡単な装置で確認でき、摩 摖係数や平均熱伝達率といった包括的な測定値は多くの ケースについて測定・集積されているが、抵抗低減流れ の詳細や、夜体のレオロジー的性質との関連については 末知の部分があるため、複雑形状流れの予測や溶液サン プルからの抵抗低減率推定といった工学的手段はまだ不 足している。

そこで本報では、界面活性剤による抵抗低減現象解明 の一助として、抵抗低减チャンネル流れの可視化、2 次 元レーザードップラー流速計（LDV）によって測定した 乱流統計量について述べ、あわせて温度変動の積分スケ 一ルの測定結果について報告する。

\section{2. 実験装置と実験方法}

Fig. 1 は、可視化および乱流測定のために用いた回

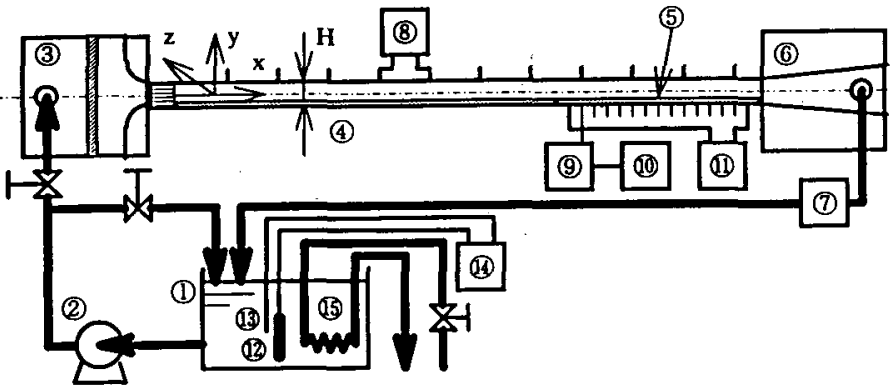

Fig. I Schematic Diagram of Closed Loop Flow Apparatus (1) Storage Tank (2) Pump (3) Contraction (4) Two Dimensional Channel $(H=40 \mathrm{~mm}, W=500 \mathrm{~mm}, L=6 \mathrm{~m}$ (5) Heater Plate (6) Diffuser (7) Flow Meter (8) Pressure Gauge (9) Data Logger (10) Personal Computer. (11) Voltage Regulator (12) Heater (13) Thermo couple (14) Heater Regulator (15) Coolin Coil

流水槽の概念図である。水槽は溶液タンク(1)、温度調節 装置(44)、ポンプ(2)、電磁流量計(7)を備えている。縮流部 (3)、試験部(4)、ディフューザー部(6)は流れの概要把握、 可視化とL D V 測定に便利であるように厚さ $20 \mathrm{~mm}$ の透 明アクリル樹脂で構成した。また LDV により光学アク セスが容易になるように、流路の断面は高さ $40 \mathrm{~mm}$ 幅 $500 \mathrm{~mm}$ の矩形とした。断面の縦横比は 12.5 と大きいの で、スパンの中央近くで平面 2 次元的流执ができている ものと見なせる。試験部長さは $6 \mathrm{~m}$ であり、主たる測定 


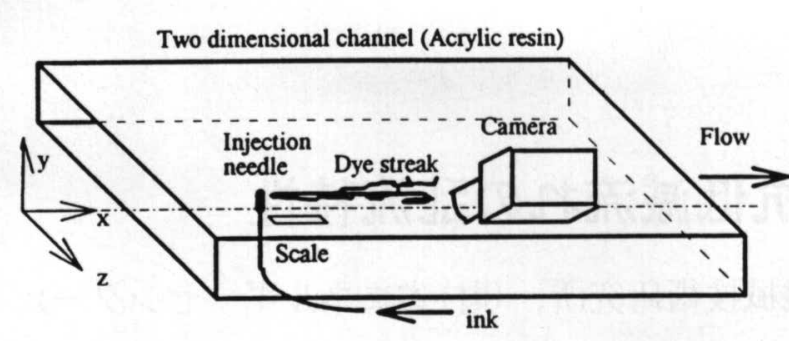

Fig. 2 Schematic View of Flow Visualization

は試験部入りロから $5 \mathrm{~m}$ の位置に設けた光学窓を通して 行った。この位置で流れは十分発達しているものと見な せる。座標系は慣行に従って主流方向を $x$ 、壁と垂直方 向に $y$ 、スパン方向に $z$ 軸をとる。

可視化測定は、チャンネルの床面から㨂入した注射針 から墨汁を注入し、写真撮影することによって行った。 注射針の先端はチャンネルの中央近くにおいた。墨の注 入速度は針先端位置の速度に合わせるようにしている。 撮影の概念図をFig. 2 に示す。

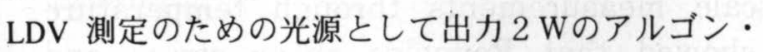
イオンレーザ、光学系は 2 カラー 3 ビーム方式、前方散 乱型のものを用いた。Fig. 3 は LDV 測定のための光学 系を示したものである。信号処理にはカウンター型処理 器を用い、パーソナルコンピュータにデータを記録し、 乱強度、結合確率密度、4象限分析といった統計処理 を行った。

温度をトレーサーとした乱れスケールの測定のために は、チャンネルの床面にステンレス鋼䇴を張り、これに 通電加熱することによって不均一な温度場をつくり、そ こで検知部直径 $50 \mu \mathrm{m}$ の細線熱電対を用いて温度変動の 時系列デー夕を記録した。その記録を分析して積分時間 スケールを算出した。水の熱伝達率は十分高いものと見 なして、熱電対の時定数に対する補償はしていない。

用いた界面活性剂は陽イオン性で第 4 級アンモニウム 塩に分類される塩化セチルトリメチルアンモニウム (CTAC) である。界面活性郕は水中で球状のミセルを 形成するが、サリチル酸を適量加えることによりミセル は棒状となり、相互に絡み合うことによって溶液に顕著 な粘弾性を与える。以下に CTAC X ppm と記す場合は、

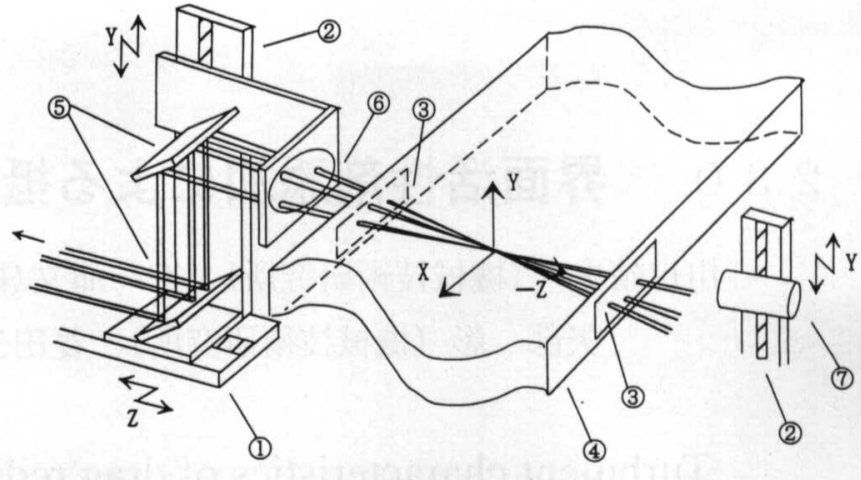

Fig. 3 LDV Measurement System Including Traverser (1) Traverser Mechanism (y-direction) (2) Traverser Mechanism (z-direction) (3) Optical Window (4) Water Channel (5) Mirror (6) Front Lens (7) Photomultiplier Optics

同重量濃度のサリチル酸も含むことを意味する。界面活 性剤を添加するとせん断粘性率も上昇するが、今回用い た濃度範囲ではせん断粘性率の上昇はさほどではないの で、テー夕の整理には溶媒である水の粘性率を用いてい る。

\section{3. 実験結果と考察}

\section{1 染料注入による可視化撮影}

Fig. 4a に、界面活性䬉水溶液（濃度 100ppm）中の 流れを染料で可視化した写真を示す。レイノルズ数は 17500 である。対比のため、界面活性剤を含まない水の 場合で、同じレイノルズ数の流れを同様に可視化した写 真を Fig. 4b に示す。Fig. 4b を見ると染料で染められ た部分は渦スケール相当の凹凸を持ち、下流にゆくほど 広がるとともに全体に薄くなってゆき、典型的な乱流拡 散の様子を示している。ビデオ画像によると、染料の形 も時々刻々変化しており、種々のスケールの渦が活発に 運動しているようすが見て取れる。これに対して、Fig. 4aに示す界面活性剤を添加した場合には、染料で染め られた流脈は糸状となっており、流れは拡散性に乏しい ことが推察される。糸状の流脈は、同じ位置では上下に 波打つように見えるが、その程度は Fig. 4a に比べると きわめて小さい。
Fig. 4a Dye Streak in Surfactant Solution FIow (CTAC 100ppm, $\mathrm{Re}=17500$ )
Fig. 4b Dye Streak in Water Flow $(\mathrm{Re}=17500)$

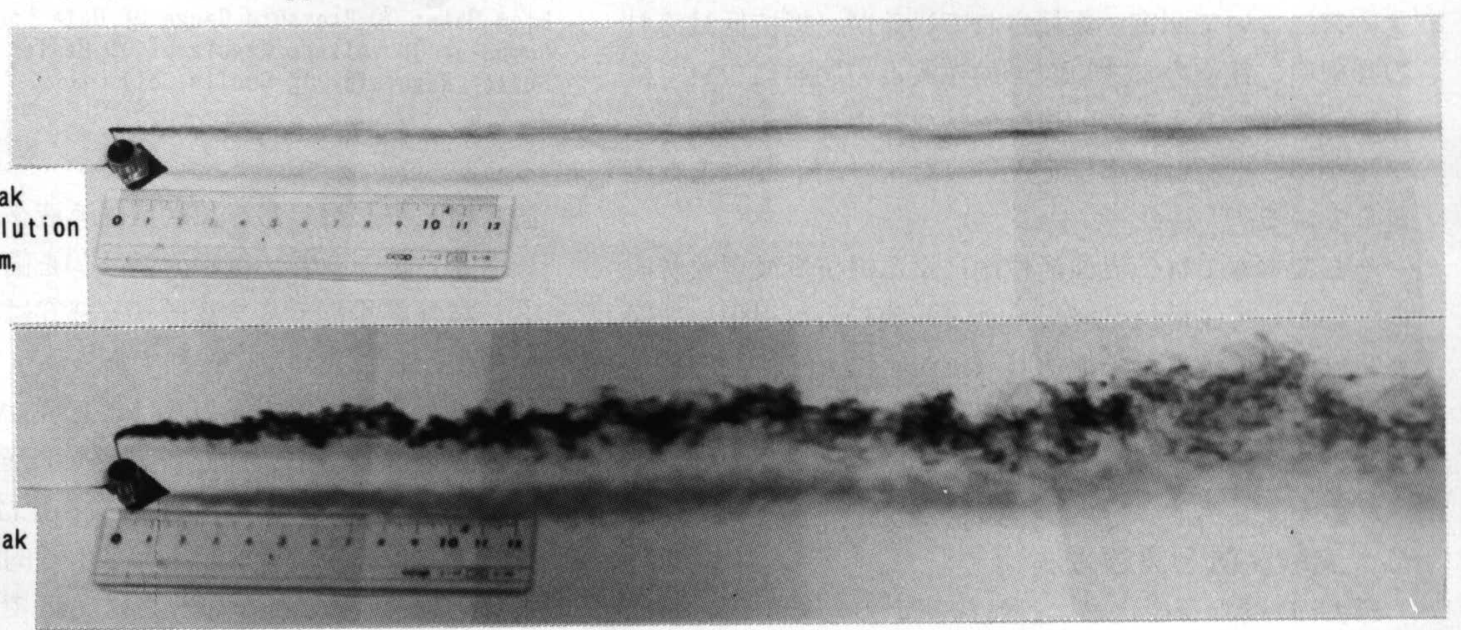




\section{2 LDV による速度変動の測定}

種々の界面活性剂濃度の溶液流れに対し、LDV を用 いて平均速度 $U$ 亡乱れ変動強度 $u^{\prime}, v^{\prime}$ のチャンネル高さ 方向の分布を測定した。レイノルズ数は 22000 であり、 この濃度範囲において静圧测定から定めた抵抗低減率は $60 \%$ 内外の值を示している。抵抗低减が顕著な場合、平 均速度は乱流に典型的な $1 / 7$ 乗則と、層流における放物 線型速度分布との中間的なものとなる。乱れ強度の絶対 值は抵抗低減のない水の流れの場合と比べると低下する が、摩擦速度で無次元化するとu'は水の場合と比べて同 程度、 $v^{\prime}$ 半分程度となることがわかった。このように、 抵抗低減流れであっても乱れは存在しており、異なる方 向成分の強度間の差が開く傾向になる。

Fig. 5 に、 $u$ と との相互相関であるレイノルズせん 断応力-̄v の分布を示す。界面活性剤を加えた場合、ど の濃度であってもレイノルズせん断応力の值は負か $0 に$ 近い值を持ち、水の場合とは大きく異なる。平均速度の 勾配は存在しており、 $x$ 方向の速度変動成分と $y$ 方向の それとの相関が存在しないことは混合距離仮設が近似的 にも成り立たない事を示している。この現象は、ポリマ 一による抵抗低減流れにおいても報告されており、抵抗 低減現象と密接に関連するものと考えられる。

レイノルズせん断応力の消失に伴って、乱流運動のコ ヒーレント構造がどのように変化しているかを調べた。

Fig. 6 は $u$ とvとの結合確率密度 $P u v$ の大きを $u$-v 平 面の中の等高線で示したものである。通常の流れでは大 きな振幅の運動に $u$ と $v$ との相関が顕著になる結果、等 高線は左上から右下に向かう方向に伸びた棈円型となる のが普通で、この研究でも水の場合にはFig. 6a に示す ように、傾いた楕円型の等高線が見て取れる。一方界面 活性剂を添加すると、Fig. 6b のように結合確率密度は 棈円型の等高線はもつものの、長軸は $u$ 方向を向いてお り、大振幅運動間の相関がなくなることがわかる。4象 限分析を試みた結果からも同じ結論が導かれる。Fig. 7 引 は、 $u$ と $v$ との符号に従って乱流運動を 4 つの象限に分 这 類し、象限毎に $\overline{u v} に$ 対する寄与を積算したもので、通 常のせん断乱流で $d U / d y>0$ であれば、第 2 象限 $(\mathrm{i}=2)$ に属 する Sweep 的運動と第 4 象限(i=4)に属する Ejection 的運 動が卓越するのが普通である。しかしながら抵抗低減流 れでの観測結果である Fig. 7 をみると、4つの象限に さほど差異はなく、むしろ第 1 、第 3 象限に属する Interaction 運動が大きな寄与をなすことがわかる。

\section{3 温度変動のスケール}

LDV による速度変動の測定結果から、大きな振幅を もつ運動の界面活性剂添加による変化がわかったが、 LDV の原理上の問題から、速度の時系列信号は得られ ない。そこで、チャンネルの一部を加熱して温度変動を 発生させ、これをトレーサーとして流れに関する情報を 推察することを試みた。温度変動と速度変動との相関係 数は 1 ではなく、また温度のスケールと速度のスケール とは大きさが異なるため、温度変動は速度変動を忠実に

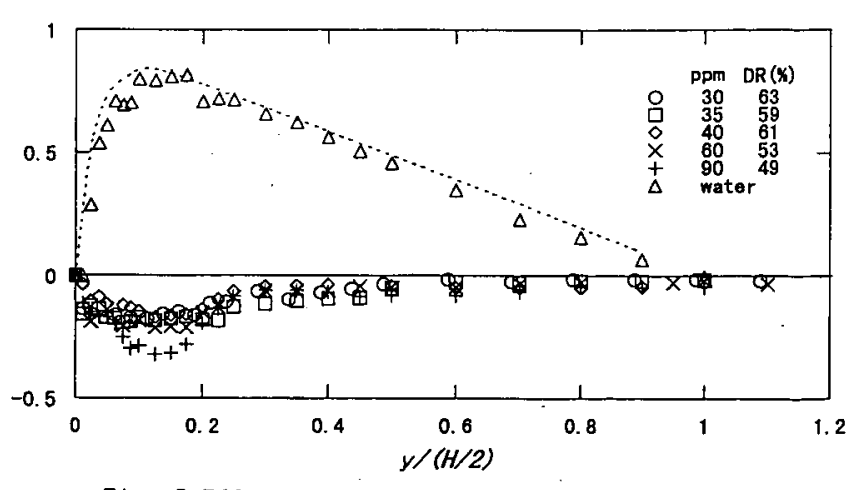

Fig. 5 Effect of surfactant Additives for Profiles of Reynolds Shear Stress -uv

(CTAC 30pom-90ppm, $\operatorname{Re}=22000$ ) Ut: Frictional Velocity

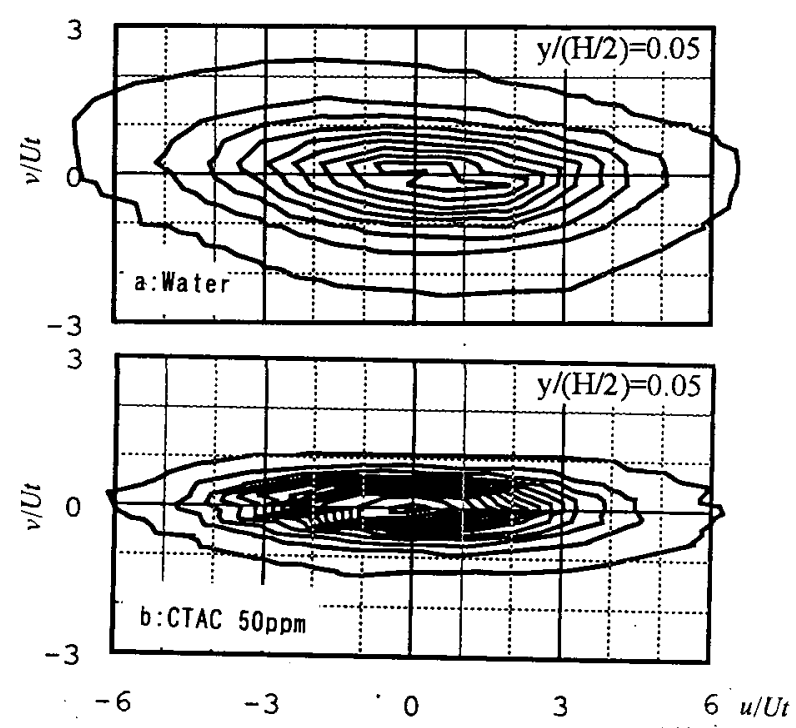

Fig. 6 Contour of Joint Probability Density Puv in $u-v$ plane $(\operatorname{Re}=55000)$

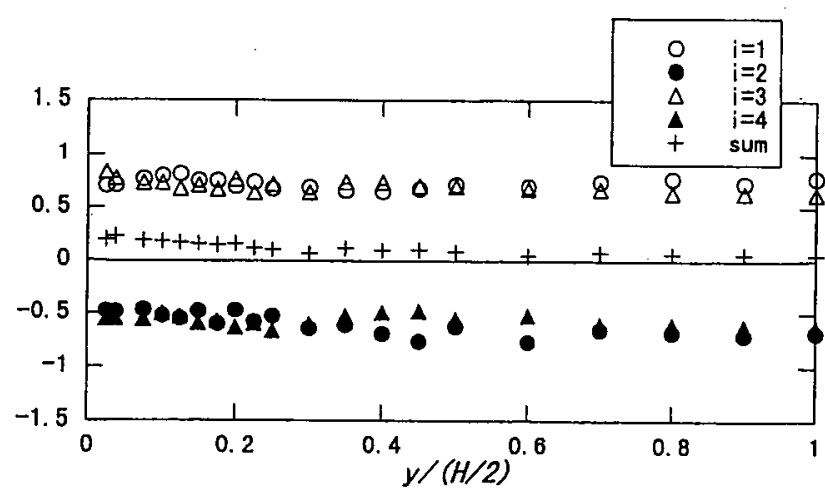

Fig. 7 Quadrant Analysys of Velocity Fluctuation ( $R e=22000$, CTAC 30ppm)

は表さないが、界面活性剂を添加した効果がスケールに 及ぼす影響をみる目的には役立つ。

$2 つ の$ 代表的な測定点 $(y /(H / 2)=0.025$ と 0.15$)$ で得ら れた温度変動波形を Fig. 8 に示す。界面活性剂を添加 しない Fig. 8a の場合、温度変動は周期の短い変動成分 からなることがわかる。これに対して、界面活性剂を加 えた Fig. $8 \mathrm{~b}$ の場合、変動周期は長くなる。このことを 定量的に表すため、温度变動の自己相関関数を計算し、 


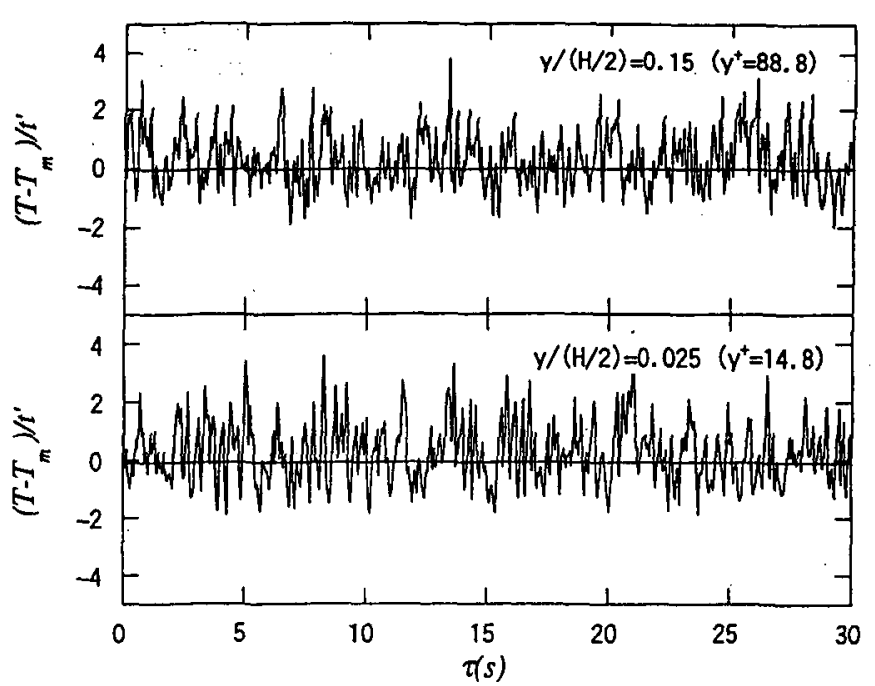

Fig. 8a Record of Temperature Fluctuation $\left(R_{e}=22000\right.$, Water)

その積分值を求めることにより、温度の積分スケールを 算出した。Fig. 9 は界面活性剂を添加した場合と添加 しない場合に対して、温度の積分スケ一ルの分布を比較 したものである。界面活性剤を添加すると、壁近くで積 分スケールがきわめて大きくなることがわかる。

このことから類推すると、壁近傍の乱れの消散率は小 さく、3．2でみたようにコヒーレント構造も弱いこと から、乱れ発生率も同時に小さくなっていることが想像 される。また、乱れの異方性が大きいことから、乱れの エネルギー再配分も弱くなっているここが想像され、中 規模から小規模の渦は不活発になり、これによって乱流 挔散の乏しい状濯がうみだされているものと考えられる。

\section{4.まとめ}

界面活性剂の添加により、60\%程度抵抗の低減した流 れに対して、以下の事が観察された。（1）染料注入法 による可視化では、同じレイノルズ数の水流に比べて抎 散性がそしく、不規則な渦運動が存在しない状況が観察 された。（2）LDVによる速度測定から、平均流れ分布 は発達した乱流と層流との中間になり、乱れ強度は弱ま るが消失するわけではない。（3）レイノルズせん断応 力は０に近い值を示す。（4）このことはコヒーレント な渦運動の消隇によって 2 方向の速度変動の相関が消失 することに起因する。（5）壁近傍の変動スケ一ルは大 きくなっており、壁近傍の乱れ消散率は小さいことが想 像できる。（6）乱れの異方性が大きいことから、乱れ の再配分も小さいことも想像され、このことが乱流拡散 のそしい状況と対応すると考えられる。

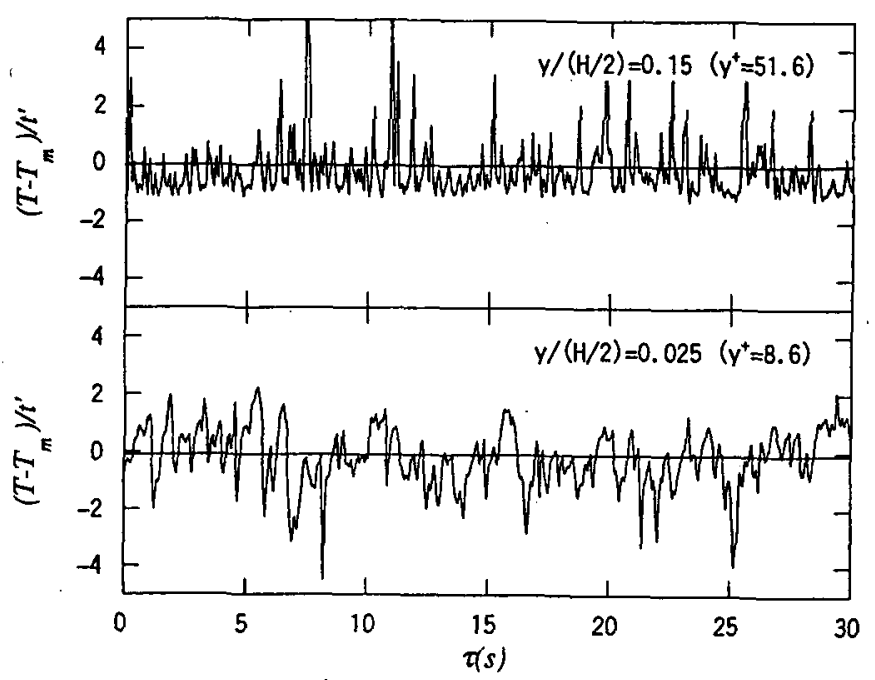

Fig. 8b Record of Temperature Fluctuation $(\mathrm{Re}=22000, \quad \mathrm{CTAC} 30 \mathrm{ppm})$

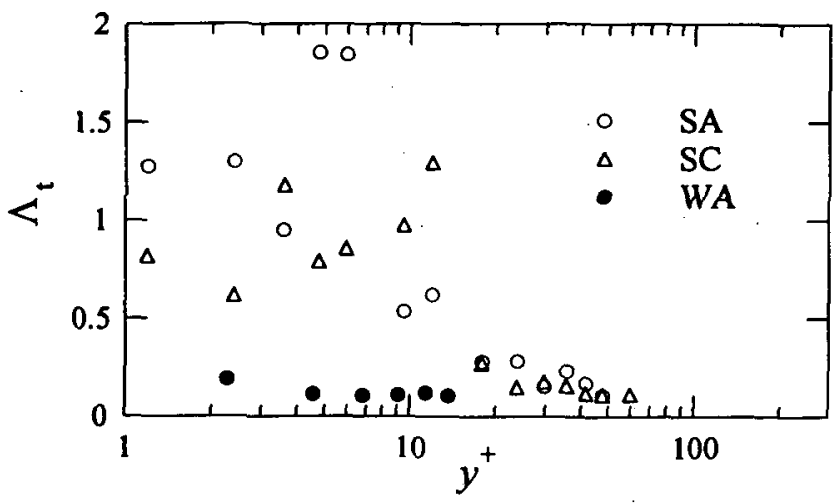

Fig. 9 Integral Time Scale of Temperature Fluctuation in Thermal Boundary Layer with and wi thout Surfactant Additives $\mathrm{Re}=12000$ (SA: CTAC 30ppm, $q_{w}=4200 \mathrm{w} / \mathrm{m}^{2}, \mathrm{SC}$ : CTAC 30ppm, $q_{w}=9300 \mathrm{~W} / \mathrm{m}^{2}$, WA: Water, $q_{w}=9300 \mathrm{w} / \mathrm{m}^{2}$ )

\section{参苦文献}

1) 棚沢一郎 (監修)：「エコ・エネ都市システム, 21 世紀の都 市エネルギーと熱利用技術」，第 3 章 6 節，界面活性剤利用流 動抵抗低減技術，（財）省エネルギーセンター(1999), 117

2) Y. Kawaguchi et al.: Active control of turbulent drag reduction in surfactant solutions by wall heating, ASME Fluid Eng. Div. Conf., FED 237-2(1996), PP.47-52

3) Y. Kawaguchi et al.: Existence of double diffusivity fluid layers and heat transfer characteristics in drag reducing channel flow, Proc. 2nd Int. Symp. Turbulence, Heat and Mass Transfer, K. Hanjalic and T.W.J. Peeters ed., Delft University Press, 1(1997), PP.157-166.

4) Y. Kawaguchi et al.: Study on a thermal boundary layer of drag reducing surfactant solution: measurements of temperature fluctuation, Proc. ASME Fluid Eng. Div. FED 244(1997), PP.375-380.

5) P.W. Li et al.: Experimental investigation of heat transfer enhancement for turbulence drag-reducing flow in a two-dimensional channel, Proc. 2nd EF conference on Turbulent Heat Transfer(1998), PP.P-21-P-29.

6) P.W. Li et al.: Control of Drag-Reduction by Channel Height Modification - Transitional Turbulent Characteristics from DragReducing Flow to Turbulent Flow, Proc. 5th ASME/JSME Joint thermal engineering conference(1999), AJTE99-6446. 